\title{
Influence of arterial hypertension treated with losartan on skin healing in rats ${ }^{1}$
}

\author{
Influência da hipertensão arterial tratada com losartan \\ na cicatrização de feridas cutâneas em ratos
}

\author{
Maria de Lourdes Pessole Biondo-Simões ${ }^{2}$, Ana Denise Zazula ${ }^{3}$, Ariana Braga Gomes ${ }^{3}$, Caroline Poncio ${ }^{3}$, Luiz Fernando \\ Bleggi Torres $^{4}$, Karin Sodatelli Borsato ${ }^{5}$ \\ 1. Research performed at the Pharmacology and Experimental Pathology Laboratories, Medical School, Pontifícia Universidade Católica \\ do Paraná (PUCPR). Brazil. \\ 2. PhD, Professor of Scientific Initiations Studies at PUCPR. Brazil. \\ 3. Medical Students at PUCPR. Brazil. \\ 4. PhD Department of Neuropathology, Institute of Neurology. The National Hospital for Nervous Diseases, Queen Square, London, \\ England. Professor of Experimental Pathology at PUCPR. Brazil. \\ 5. PhD, Professor at the Laboratory of Destructive Assays at PUCPR. Brazil
}

\begin{abstract}
Purpose: To evaluate the role of Losartan in skin healing repair. Methods: One hundred and eleven male Wistar rats were distributed into four groups, at random. Group I ( $n=31)$ underwent a laparotomy to induce hypertension by stenosis of the left renal artery, and 48 hours later it received Losartan $(10 \mathrm{mg} / \mathrm{Kg})$ daily. Group II ( $\mathrm{n}=30)$ went through the same procedure and received isotonic saline solution. Group III $(n=30)$ underwent a simulated laparotomy. Group IV ( $n=20)$ to confirm the induced hypertension method. Ketamine and Xylazin anesthesia was used in every painful/stressful procedure. After 15 days, skin healing repair was studied by a dorsal midline skin incision and second layer-skin incision in groups I, II and III, that was sutured in one layer with 4-0 nylon suture. Samples of the dorsal wall scar were taken 4, 7 and 14 days after the last procedure, and sent to strength and displacement analysis and histological preparation. Results: By the $4^{\text {th }}$ and $7^{\text {th }}$ days of the analysis, group II scars showed to be less resistant than group III scars $(p<0,05)$. The total amount of collagen was higher in group III on the three studied periods. The percentage occupied by total collagen in the wound area, on the $14^{\text {th }}$ day, was lower in group I, due to its lower percentage of type I collagen Conclusion: Scars treated with Losartan were initially less resistant and had a lower collagen deposition.
\end{abstract}

Key words: Wound healing, Collagen, Losartan.

\section{RESUMO}

Objetivo: Avaliar a influência do Losartan na reparação de feridas da pele. Métodos: Cento e onze ratos Wistar, machos, foram distribuídos aleatoriamente em quatro grupos. Grupo I (n=31), submetidos à laparotomia com indução de hipertensão pela estenose da artéria renal esquerda e que após 48 horas receberam Losartan (10 mg/Kg) diariamente. Grupo II (n=30) submetidos ao mesmo procedimento e que receberam solução salina isotônica. Grupo III $(\mathrm{n}=30)$ submetidos à laparotomia sem indução de hipertensão. Grupo IV ( $n=20)$ animais que serviram para a confirmação do método de indução da hipertensão. Anestesia com quetamina e xilazina foi utilizada para todos os procedimentos com dor ou estresse. Após 15 dias, a cicatrização da pele foi estudada fazendo-se uma incisão medial, no dorso, seguida de síntese com sutura de náilon 4.0, nos animais dos grupos I, II e III. As avaliações foram realizadas após 4, 7 e 14 dias verificando-se a resistência e analizandose as preparações histológicas. Resultados: No 4. ${ }^{\circ}$ e no $7 .^{\circ}$ dia as cicatrizes dos animais do grupo I eram menos resistentes do que as do grupo III $(\mathrm{p}<0,05)$. A densidade de colágeno era maior nos cortes histológicos do grupo III nos três períodos estudados. A percentagem de colágeno nos campos histológicos analisados, no $14 .^{\circ}$ dia, era menor no grupo I, devida a baixa densidade de colágeno tipo I. Conclusão: Feridas tratadas com Losartan são inicialmente menos resistentes e apresentam menor densidade de colágeno.

Descritores: Cicatrização de Feridas. Colágeno. Losartan.

\section{Introduction}

Wound healing is a complex process involving several types of cells and specific events. Studies on this matter, since its origin until the current days, have contributed to the agreement on the healing process. The final goal of tissue perfusion is a good wound oxygenation and nutrition. To optimize wound healing, factors that lead to ischemia, such as vasoconstriction, (one of the effects of angiotensin II ${ }^{(1)}$ ) must be prevented. Arterial hypertension involves many physiopathogenic mechanisms, such as the renal mechanism of renin-angiotensin-aldosterone, which leads 
to an increased arterial blood pressure, due to vasoconstriction and to the formation of angiotensin II, that causes sodium and water retention caused by aldosterone release ${ }^{(2)}$. Taking into account the role of angiotensin II, in hypertension physiopathogenic process, the study of angiotensin II blockade effects, by its receiver AT1, was found pertinent. The antagonist of angiotensin II, AT1 receptor, is associated to the inhibition of collagen I synthesis and with myocardial fibrosis regression, in rats with reno-vascular hypertension ${ }^{(3)}$. Losartan use reduces that synthesis, as well as collagen type I degradation, thus reducing myocardial fibrosis in spontaneous hypertensive rats ${ }^{(4)}$. Furthermore, it has been demonstrated that the use of Losartan lowers hypoxic pulmonary hypertension, therefore interfering with the expression of collagen in rat's pulmonary artery ${ }^{(5)}$. A recent study on rats showed the reduction of hepatic fibrosis, after inducted biliary cirrhosis ${ }^{(6)}$.

By this medication, there is interference in myocardium, pulmonary artery and liver, and it is also possible that it can interfere with cutaneous healing. That hypothesis motivated this study, whose purpose is to evaluate arterial hypertension influence treated with angiotensin II receptor antagonist (Losartan) in rats skin wound healing.

\section{Methods}

The study was conducted according to Federal Law 6638 and to the recommendations of the Brazilian College of Animal Experimentation. It was approved by the Pontifical Catholic University of Paraná (PUCR) on October 31 $1^{\text {st }}, 2003$, by the Animal Research Ethics Committee, according to the current guidelines for research involving animals. One hundred male Wistar-PUCPR rats were used on this study (Rattus norvegicus albinus, Rodentia mammalia). They were young adult rats, 90 days old and $243 \mathrm{~g}$ weight in average. They were housed in PUCPR Animals Laboratory, under partially controlled environment, i. e., light/dark 12 hours cycle, temperature $21 \pm 2^{\circ} \mathrm{C}$, moisture and noise intensity according to the general environment. The animals had free access to rat chow and water, throughout the experiment. Rats were allocated into four groups:

- Group I - experimental (n=31): underwent a laparotomy to induce arterial hypertension by stenosis of the left renal artery. Forty-eight hours later, they received, by gavage, Losartan $(10 \mathrm{mg} / \mathrm{kg})$, the anti-hypertensive antagonist of angiotensin AT1 receptor;

- Group II - hypertensive control (n=30): went through the same operation and received, by gavage, one milliliter of isotonic saline $0,9 \%$ solution;

- $\quad$ Group III - control ( $\mathrm{n}=30)$ : underwent a simulated laparotomy;

- Group IV - blood pressure checking group ( $n=20): 10$ rats with induced reno-vascular hypertension and 10 rats that went through a simulated laparotomy, on the last day of the experiment. All 20 animals had their blood pressure measured directly on the aorta, in order to test the method used to induce hypertension.
Intramuscular anesthesia with $0,2 \mathrm{ml} / 100 \mathrm{~g}$ of the mixture of $1 \mathrm{ml}$ ketamine $(50 \mathrm{mg} / \mathrm{ml})$ and $1 \mathrm{ml}$ of xylazin $2 \%(20 \mathrm{mg} / \mathrm{ml})$ was used in every painful/stressfull procedure. Animals' abdomen were shaved and disinfected with polyvinylpyrrolidone-iodine. The animals were immobilized on the surgical plane-table by fixation of their cranial and caudal members with adhesive tape. A median 3 centimeters laparotomy was performed. Planes involved were skin, subcutaneous tissue, aponeurosis and parietal-peritoneum. Then, the left renal artery stenosis was made, with twisted multifilamentar cotton sutures 3.0 , followed by a laparorrhaphy on two synthesis planes. The peritoneummuscle-aponeurosis using continuous 4.0 nylon sutures and the skin using separated suture of the same synthesis material. Before recovery from anesthesia, the animals were weighed in order to calculate the anti-hypertensive dose. After that they were returned to their cages, for postoperative attendance.

The animals received their medication daily, after 48 hours since the surgical intervention. The drug was diluted in one milliliter of $\mathrm{NaCl}$ isotonic $0,9 \%$ saline solution for the experimental group animals. In order to study skin healing repair, after 15 days of treatment with anti-hypertensive, a dorsal midline longitudinal skin incision and second-layer skin was performed in groups I, II and III. The incision was about four centimeters long and it was sutured in one layer with monofilament 4.0 nylon suture.

Ten animals per group were sacrificed by a lethal intraperitoneal dose of sodic thiopental, and by drawing lots on the $4^{\text {th }}, 7^{\text {th }}$ and $14^{\text {th }}$ day after skin incision. The skin wound was then resected together with $0.5 \mathrm{~cm}$ of adjacent skin above and below its limits and $2.0 \mathrm{~cm}$ laterally on both sides. Skin slices were stretched on filter paper, divided into two pieces and placed into flasks, one containing physiological saline solution $0,9 \%$ for tensile analysis, and the other containing $10 \%$ formalin, for histological analysis. On withdrawal day the fragments were tested for maximum strength (in Newtons) and displacement (in centimeters) in an EMIC ${ }^{\circledR}$ traction machine (PUCPR Laboratory of Destructive Analysis). Maximum strength was considered to be the greatest strength or load applied to the specimens up to their rupture. The force was always applied perpendicular to the wound, in an attempt to separate its margins. Conventional histological preparations were performed from the skin slices, obtaining four micrometers sections from the paraffin blocks. The sections were stained with hematoxylin-eosin (to evaluate the general aspects) and with Sirius red (to observe collagen deposition).

In the Sirius Red optic microscopy, the stained material was analyzed at 200X magnification, using an Olympus ${ }^{\circledR}$ BX-50 optic microscope with polarized light. The thicker collagen fibers represent collagen I and they appeared stained in yellow and red shades. Collagen III fibers were thinner and dispersed, and dyed in green shades. Images were obtained by means of a Sony ${ }^{\circledR}$ CCD-Iris camera. They were sent to a Del monitor, colored, frozen and analyzed, and were analyzed by means of the applicatory Image ProPlus $^{\circledR} 4.0$ for Windows in an Intel Inside ${ }^{\circledR}$ computer type 
Pentium 4. The percentages occupied by fibers of collagen types I and III had been analyzed and calculated in five fields, from which an average of each reading was obtained. Total collagen corresponded to the sum of collagen I and III percentages.

Reepithelialization, inflammatory reaction, granulation tissue and fibrosis were used to analyze the hematoxylineosin stained samples, according to the following criteria:

- reepithelialization:

o incomplete: existence of fibrin-leukocyte crust on the wound with discontinuous epithelial tissue;

o complete: absence of solution of epithelial tissue continuity.

- inflammatory reaction:

o pronounced: infiltration of inflammatory cells visible at optic microscope small magnification $(10 \mathrm{X})$;

o moderate: identification of neutrophylic infiltrated visible at $100 \mathrm{X}$ magnification;

o discrete: viewed at $200 \mathrm{X}$ magnification.

- granulation tissue:

o type A: great amount of fibroblasts in small collagen matrix, without edema, somewhat visible at $10 \mathrm{X}$ magnification in a few vessels;

o type B: granulation tissue with edema, quite visible at $10 \mathrm{X}$ magnification, in many vessels, indicating a pronounced neo-angiogenesis.

- $\quad$ fibrosis: presence of a few fibroblasts nuclei showing an evidently organized collagen matrix. Absence of inflammatory process and few capillaries, indicating advanced healing process.

On the 14th day, arterial blood pressure in abdominal aorta was measured in the 20 animals of the blood pressure checking group. In order to evaluate this group blood pressure, the animals were anesthetized and underwent laparotomy. The abdominal aorta was dissected, its distal portion tied with twisted 2.0 cotton suture and its proximal portion arranged to allow for the temporary closing of the aorta. A small incision in the anterior wall was made and the proximal portion was cannulated with a $4 \mathrm{~F}$ catheter, connected to a Y system that held the manometer. For this procedure, heparin solution was injected into the animal's penis dorsal vein.

Data were statistically analyzed using variance to a factor for the comparison of the groups related to the study variables and the Newman-Keuls' test for the comparison two by two of the groups in case of null hypothesis' rejection. Variables that did not fit the conditions of symmetry and homogeneity of the variances underwent to the square shaped root transformation. Fischer test was used for the $2 \mathrm{X} 2$ tables. The level of significance was set at $\mathrm{p}<0.05$.

\section{Results}

During the experimental period, three animals of the hypertensive control group and two from the experimental group died. Among those who died, bleeding urine, epistaxis and ocular hemorrhage were observed. The tensile strength test showed that, on the $4^{\text {th }}$ day, scars from the hypertensive untreated animals had offered less resistance than those from the treated hypertensive animals and control group (Table 1 and Figure 1).



FIGURE 1 - Graphic of the profit and the behavior of the resistance among the groups

TABLE 1 - Scar rupture strength $4^{\text {th }}, 7^{\text {th }}$ and $14^{\text {th }}$ days (Newtons)

\begin{tabular}{|c|c|c|c|c|c|c|c|c|}
\hline Variable & Group & $\mathrm{n}$ & Minimum & Maximum & Median & $\begin{array}{l}\text { Mean } \\
\text { rate }\end{array}$ & $\begin{array}{l}\text { Standard } \\
\text { Deviation }\end{array}$ & $\mathrm{p}$ value \\
\hline & I & 10 & 0,53 & 1,43 & 0,76 & 0,89 & 0,33 & \\
\hline Resistance & II & 7 & 0,19 & 1,80 & 0,38 & 0,57 & 0,56 & 0,0285 \\
\hline \multirow[t]{2}{*}{ 4th day } & III & 9 & 0,27 & 3,18 & 1,63 & 1,48 & 0,94 & \\
\hline & I & 10 & 1,51 & 4,05 & 2,33 & 2,40 & 0,75 & \\
\hline Resistance & II & 8 & 0,73 & 4,88 & 1,27 & 1,68 & 1,32 & 0,1990 \\
\hline \multirow[t]{2}{*}{ 7th day } & III & 9 & 0,84 & 4,37 & 2,69 & 2,46 & 1,32 & \\
\hline & I & 10 & 2,01 & 6,35 & 3,93 & 4,17 & 1,40 & \\
\hline Resistance & II & 6 & 1,90 & 5,88 & 3,65 & 3,86 & 1,42 & \\
\hline 14th day & III & 9 & 2,20 & 6,24 & 3,53 & 3,59 & 1,29 & \\
\hline
\end{tabular}


In skin scars microscopic sections stained with Sirius red, it was observed that the total collagen concentration was more intense, both I and III fractions, in the control group, in all three studied periods. In the beginning of the healing process, no significant difference was observed on the total amount of collagen as in type I experimental and hypertensive control groups. Meanwhile, on the $14^{\text {th }}$ day, the experimental group had lower total collagen concentration ( $p=0,0404)$, due to a lower type I collagen percentage $(p=0,0040)$ detected in the scars of this treated hypertensive group (Tables 2, 3 and 4; Figure 2).

For reepithelialization, the intensity of the inflammatory reaction and the formation of granulation tissue and fibrosis were similar in the three groups. Blood pressure analysis of the checking group animals was useful to determine their blood pressure and the effectiveness of the hypertension induction method. Every animal subjected to stenosis of the left renal artery developed arterial hypertension. While the blood pressure of the animals in the group which underwent to a simulated laparotomy was $83.18 \pm 7.51 \mathrm{mmHg}$, in those which induced hypertension procedure was performed it was $151.36 \pm 10.51 \mathrm{mmHg}(\mathrm{p}<0,05)$.

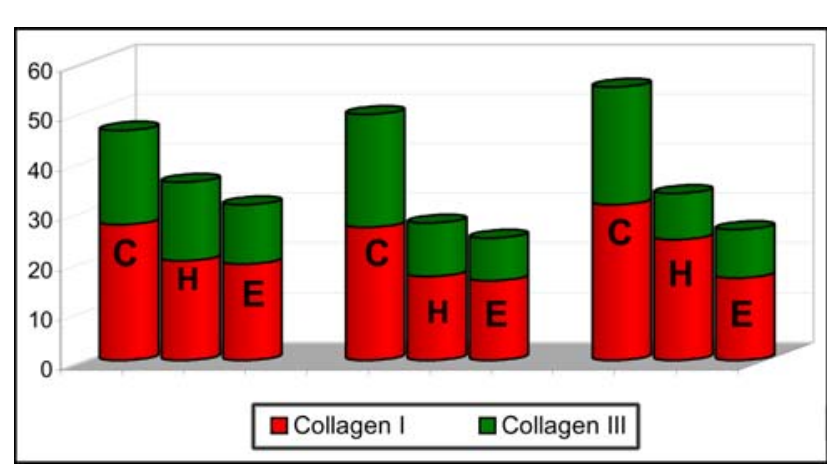

FIGURE 2 - Graphic that shows the total collagen density and its types I and III over the three studied periods $(\mathrm{C}=$ control; $\mathrm{H}=$ hypertensive control; $\mathrm{E}=$ experimental)

TABLE 2 - Collagen average on $4^{\text {th }}$ day Sirius red stained skin scars

\begin{tabular}{|c|c|c|c|c|c|c|c|c|c|}
\hline & \multicolumn{3}{|c|}{ Control } & \multicolumn{3}{|c|}{ Hypertensive control } & \multicolumn{3}{|c|}{ Experimental } \\
\hline & Collagen I & Collagen III & Total & Collagen I & Collagen III & Total & Collagen I & Collagen III & Total \\
\hline & 22,05 & 13,71 & 35,76 & 19,97 & 11,07 & 31,04 & 14,82 & 15,31 & 30,13 \\
\hline & 28,73 & 15,11 & 43,84 & 14,09 & 13,32 & 27,41 & 9,91 & 14,2 & 24,11 \\
\hline & 33,18 & 17,98 & 51,16 & 21,01 & 17,53 & 38,54 & 24,32 & 10,96 & 35,28 \\
\hline & 27,45 & 23,82 & 51,27 & 22,87 & 23,28 & 46,15 & 19,02 & 10,39 & 29,41 \\
\hline & 24,33 & 25,48 & 49,81 & 35,89 & 13,73 & 49,62 & 25,16 & 14,65 & 39,81 \\
\hline & 36,51 & 20,44 & 56,95 & 24,67 & 16,7 & 41,37 & 26,22 & 13,81 & 40,03 \\
\hline & 19,89 & 27,14 & 47,03 & 9,69 & 10,75 & 20,44 & 15,83 & 7,46 & 23,29 \\
\hline & 25,66 & 15,23 & 40,89 & 15,49 & 15,09 & 30,58 & 16,07 & 7,18 & 23,25 \\
\hline & 28,83 & 17,62 & 46,45 & 16,92 & 20,54 & 37,46 & 23,52 & 13,15 & 36,67 \\
\hline & 26,39 & 13,88 & 40,27 & $*$ & $*$ & $*$ & $*$ & $*$ & $*$ \\
\hline Mean rate & 27,3 & 19,04 & 46,34 & 20,07 & 15,78 & 35,84 & 19,43 & 11,9 & 31,33 \\
\hline Maximum & 36,51 & 27,14 & 56,95 & 35,89 & 23,28 & 49,62 & 26,22 & 15,31 & 40,03 \\
\hline Minimum & 19,89 & 13,71 & 35,76 & 9,69 & 11,07 & 20,44 & 9,91 & 7,18 & 23,25 \\
\hline Standard & & & & & & & & & \\
\hline Deviation & 4,93 & 4,94 & 6,3 & 7,54 & 4,2 & 9,32 & 5,65 & 3,06 & 6,88 \\
\hline \% Stand & & & & & & & & & \\
\hline Dev & 18,06 & 25,94 & 13,59 & 37,56 & 26,61 & 26,01 & 29,11 & 25,7 & 21,96 \\
\hline \multicolumn{10}{|c|}{ * animal death } \\
\hline \multirow{2}{*}{\multicolumn{3}{|c|}{ Compared groups }} & \multicolumn{2}{|r|}{ Collagen I } & & Collagen III & \multicolumn{3}{|c|}{ Total Collagen } \\
\hline & & & \multicolumn{2}{|r|}{$\mathrm{p}$ value } & & $\mathrm{p}$ value & \multicolumn{3}{|c|}{$\mathrm{p}$ value } \\
\hline \multicolumn{3}{|c|}{$\begin{array}{l}\text { control } \mathrm{x} \text { hypertensive control } \\
\text { control x experimental }\end{array}$} & \multicolumn{2}{|r|}{0,0170} & & 0,1045 & \multicolumn{3}{|c|}{0,0063} \\
\hline \multirow{2}{*}{\multicolumn{3}{|c|}{$\begin{array}{l}\text { control x experimental } \\
\text { hypertensive control x experime }\end{array}$}} & \multicolumn{2}{|r|}{0,0263} & & 0,0031 & \multicolumn{3}{|c|}{0,0008} \\
\hline & & & \multicolumn{2}{|r|}{0,8237} & & 0,0562 & \multicolumn{3}{|c|}{0,2100} \\
\hline
\end{tabular}


TABLE 3 - Collagen average on the $7^{\text {th }}$ day Sirius red stained skin scars

\begin{tabular}{|c|c|c|c|c|c|c|c|c|c|}
\hline & \multicolumn{3}{|c|}{ Control } & \multicolumn{3}{|c|}{ Hypertensive Control } & \multicolumn{3}{|c|}{ Experimental } \\
\hline & Collagen I & Collagen III & Total & Collagen I & Collagen III & Total & Collagen I & Collagen III & Total \\
\hline & 27,73 & 12,56 & 40,29 & 21,15 & 13,11 & 34,26 & 18,83 & 9,59 & 28,42 \\
\hline & 29,6 & 22,57 & 52,17 & 29,86 & 21,39 & 51,25 & 14,41 & 5,37 & 19,78 \\
\hline & 23,26 & 28,41 & 51,67 & 14,8 & 11,8 & 26,6 & 13,93 & 9,46 & 23,39 \\
\hline & 35,49 & 29,18 & 64,67 & 14,83 & 8,02 & 22,85 & 14,65 & 6,83 & 21,48 \\
\hline & 23,36 & 16,82 & 40,18 & 26,2 & 9,63 & 35,83 & 10,96 & 3,27 & 14,23 \\
\hline & 30,91 & 28,69 & 59,6 & 13,98 & 8,62 & 22,6 & 9,09 & 6,3 & 15,39 \\
\hline & 17,84 & 29,87 & 47,71 & 13,92 & 13,09 & 27,01 & 21,47 & 8,03 & 29,5 \\
\hline & 25,36 & 21,93 & 47,29 & 14,85 & 6,44 & 21,29 & 14,44 & 7,3 & 21,74 \\
\hline & 27,88 & 19,98 & 47,86 & 6,01 & 6,64 & 12,65 & 27,51 & 19,86 & 47,37 \\
\hline & 26,01 & 17,64 & 43,65 & 13,93 & 8,08 & 22,01 & $*$ & $*$ & $*$ \\
\hline Mean rate & 26,74 & 22,76 & 49,51 & 16,95 & 10,68 & 27,63 & 16,14 & 8,44 & 24,59 \\
\hline Maximum & 35,49 & 29,87 & 64,67 & 29,86 & 21,39 & 51,25 & 27,51 & 19,86 & 47,37 \\
\hline Minimum & 17,84 & 12,56 & 40,18 & 6,01 & 6,44 & 12,65 & 9,09 & 3,27 & 14,23 \\
\hline Standard & & & & & & & & & \\
\hline Deviation & 4,82 & 6,08 & 7,89 & 6,91 & 4,49 & 10,62 & 5,64 & 4,71 & 9,95 \\
\hline \% Stand & & & & & & & & & \\
\hline Dev & 18,02 & 26,71 & 15,94 & 40,78 & 41,5 & 38,42 & 34,93 & 55,78 & 40,47 \\
\hline \multicolumn{10}{|c|}{ * animal death } \\
\hline \multirow{2}{*}{\multicolumn{3}{|c|}{ Compared groups }} & \multicolumn{2}{|r|}{ Collagen I } & \multicolumn{2}{|r|}{ Collagen III } & \multicolumn{3}{|c|}{ Total Collagen } \\
\hline & & & \multicolumn{2}{|r|}{$\mathrm{p}$ value } & & $\mathrm{p}$ value & \multicolumn{3}{|c|}{$\mathrm{p}$ value } \\
\hline \multirow{2}{*}{\multicolumn{3}{|c|}{$\begin{array}{l}\text { control x hypertensive control } \\
\text { control x experimental }\end{array}$}} & \multicolumn{2}{|r|}{0,0013} & \multicolumn{2}{|r|}{0,0002} & \multicolumn{3}{|c|}{0,0002} \\
\hline & & & \multirow{2}{*}{\multicolumn{2}{|c|}{$\begin{array}{l}\mathbf{0 , 0 0 1 5} \\
0,7643\end{array}$}} & \multicolumn{2}{|r|}{0,0001} & \multicolumn{3}{|c|}{0,0001} \\
\hline \multicolumn{3}{|c|}{ hypertensive control $\mathrm{x}$ experimental } & & & & 0,2153 & & 0,4897 & \\
\hline
\end{tabular}

TABLE 4 - Collagen average on the 14th day Sirius red stained skin scars

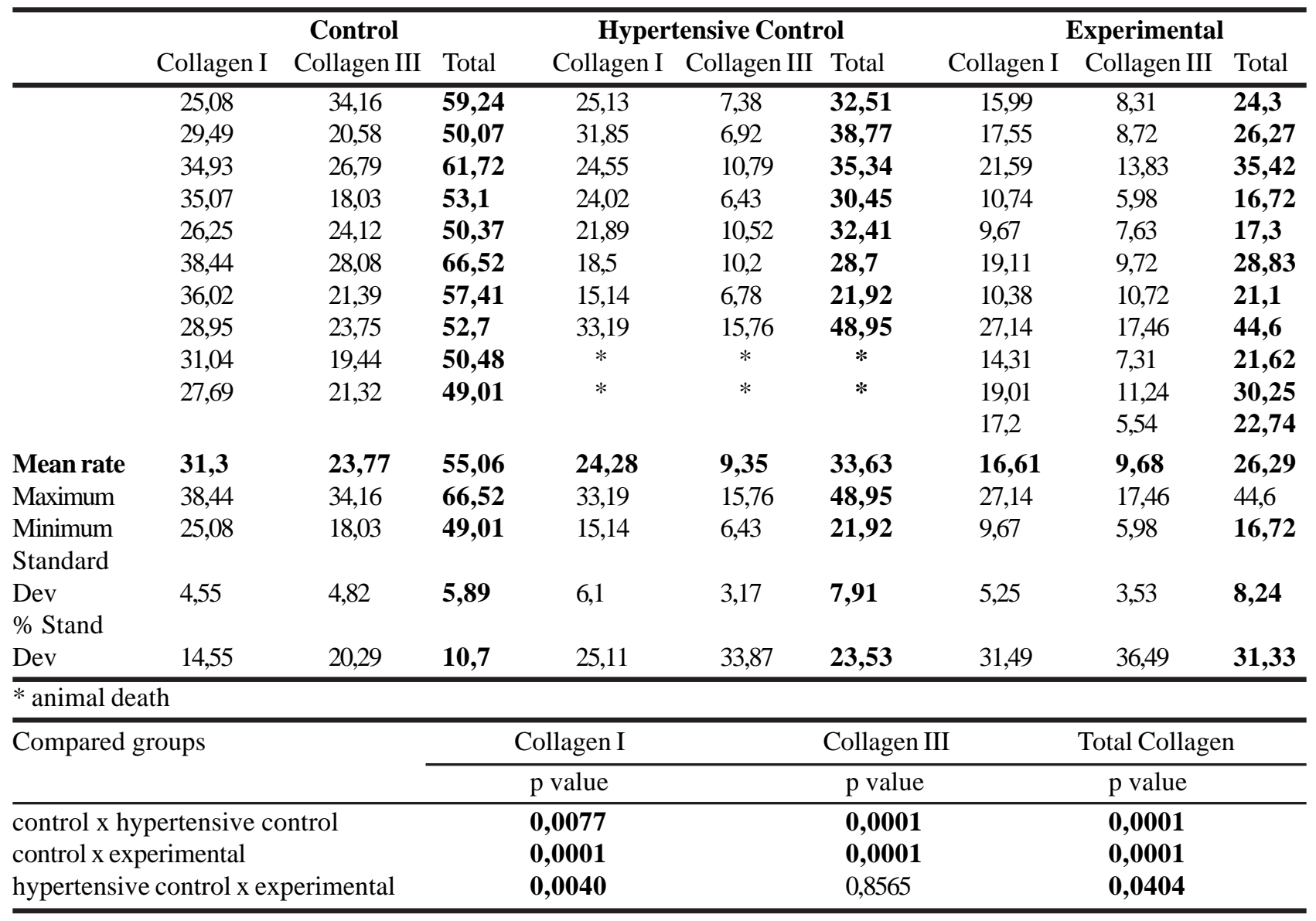




\section{Discussion}

Arterial hypertension causes endothelial dysfunction which results in contraction of the vascular smooth muscle, causing increase of the peripheral resistance and growth of the vascular wall with reduction of arterial lumen, thus determining tissue ischemia ${ }^{(7)}$.

Wound healing depends on many factors; among them there is an adequate vascularization, since the healing process evolution speed depends on oxygen. The synthesis of the collagen molecule needs an adequate oxygen concentration for proline and lysine hydroxylation and, in the final phase, for removal of the terminal peptide leading to molecule organization. The objective of an adequate tissue perfusion is a good wound oxygenation and nutrition. Thus, the tissue ischemia caused by arterial hypertension would be harmful to wound healing. In this study, this fact is confirmed by the observed damages on the collagen deposition, as well as in the group scars of the hypertensive control and experimental groups.

The method used to induce arterial hypertension was Goldblatt (2 kidney-1clip), which consists of nipping one of the renal arteries while maintaining both kidneys, this procedure produces persistent hypertension in the rat ${ }^{(8)}$. The choice of the left renal artery for stenosis is justified by the presence of the liver, which obstructs the access to the right artery. Arterial pressure suffers an abrupt increase reaching its plateau 48 hours after the induction of renovascular hypertension and its pressure level is directly proportional to the degree of stenosis. These data justify the beginning of medication 2 days after arterial hypertension induction. There is an increase of plasmatic angiotensin II in this model ${ }^{(9)}$. Although it activates specific mechanisms to increase arterial pressure, reno-vascular hypertension suffers a parallel performance from other systems, such as the sympathetic nervous system ${ }^{(10)}$ and natriuretic peptides ${ }^{(11)}$.

In this study, the confirmation of the reno-vascular hypertension induction method was carried out through with measurement of the blood pressure checking group. The animals which underwent left renal artery partial nipping had arterial pressure values of $151.36 \pm 10.51 \mathrm{mmHg}$, while the group without stenosis had $83.18 \pm 7.51 \mathrm{mmHg}$. The measurements of arterial blood pressure by the direct method, the one that uses an intra-arterial catheter; and by the indirect one, that uses the tail cuff, are equivalent. ${ }^{(12)}$.

The Losartan dose used in this study was $10 \mathrm{mg} / \mathrm{Kg}$ ${ }^{(13)}$. Increased arterial pressure causes injuries in perfused organs; the most sensitive are brain, arteries, kidneys and heart ${ }^{(14)}$. The clinical manifestations attributed to the arterial pressure rise are: epistaxis ${ }^{(15)}$, urinary alterations due to renal and retina injuries ${ }^{(16)}$. Among the dead animals it was observed urinary, nasal and ocular hemorrhage. The current study demonstrated that the scars of the hypertensive control animals, in the initial phases, are less resistant than those of the experimental and control animals. However, at $14^{\text {th }}$ day, scars resistance is equivalent among the groups.
In the Sirius red staining analysis, it was observed that the total amount of collagen, the three times studied, was higher in the control group than in the hypertensive animals (treated and untreated). Collagen I type had higher density in the control animals, and its density was similar in the hypertensive and experimental groups at the $4^{\text {th }}$ and $7^{\text {th }}$ day. But, at the 14th day a lower concentration of collagen type I was detected in the wounds of the experimental group. Collagen III density, at the $4^{\text {th }}$ day, was similar in the hypertensive control and control groups, while the rats that received Losartan, at this same period of time, had lower concentrations of collagen type III. However, in the $7^{\text {th }}$ day there was a lower concentration of collagen type III in the not treated hypertensive rats and even lower deposition of collagen in those which received the antihypertensive Losartan. In the final period ( $14^{\text {th }}$ day) there was no difference of collagen type III in the hypertensive and experimental groups; but there was a higher amount of collagen type III in the control animals when compared to the other groups. The group of animals that were treated with Losartan had a lower concentration of total collagen, due to a lower deposition of fraction I. Thus, considering the data above it can be inferred that Losartan diminishes collagen global synthesis.

The antagonist of angiotensin II receptor AT1 is associated with the inhibition of collagen I synthesis and with the regression of myocardial fibrosis in rats with renovascular hypertension ${ }^{(3)}$. Losartan use diminished both synthesis and degradation of collagen type I, then it is responsible for reducing myocardial fibrosis in spontaneous hypertensive rats ${ }^{(4)}$. It has been demonstrated that Losartan use lowers hypoxic pulmonary hypertension, by interfering with collagen expression in the pulmonary rat artery ${ }^{(5)}$. Furthermore, it is responsible for the reduction of hepatic fibrosis in rats, after the induction of biliary cirrhosis ${ }^{(6)}$. Results in skin coincide with data from other studies in which Losartan diminishes fibrosis by interference in collagen synthesis.

\section{Conclusion}

Skin scars initially treated with Losartan were less resistant, had lower deposition of collagen, and had scar ripeness delayed.

\section{References}

1. Weir MR, Dzau VJ. The renin-angiotensin-aldosterone system: a specific target for hypertension management. Am J Hypertens. 1999; 12(12Pt3):205S-13S.

2. Granger JP, Schnackenberg CG. Renal mechanisms of angiotensin II-induced hypertension. Semin Nephrol. 2000; 20(5):417-25.

3. Dussaillant GR, Gonzalez H, Cespedes C, Jalil JE. Regression of left ventricular hypertrophy in experimental renovascular hypertension: diastolic dysfunction depends more on myocardial collagen than it does on myocardial mass. J Hypertens. 1996; 14(9):1117-23.

4. Varo N, Iraburu MJ, Varela M, Lopez B, Etayo JC, Diez J. Chronic AT1 blockade stimulates extra cellular collagen 
type I degradation and reverses myocardial fibrosis in spontaneously hypertensive rats. Hypertension. 2000; 35(6):1197-202.

5. Chen S, Zhou H, Wang L. The effect of losartan intervention on the regulation of pulmonary arterial collagen expression by protein kinase $\mathrm{C}$ in chronic hypoxic rat models. Chinese J Intern Med. 2002; 41(7):444-9.

6. Ramalho LN, Ramalho FS, Zucoloto S, Castro-e-Silva Junior O, Correa FM, Elias Junior J, Magalhaes JF. Effect of losartan, an angiotensin II antagonist on secondary biliary cirrhosis. Hepatogastroenterology. 2002; 49(48):1499-502.

7. Batlouni M. Endothelium and Arterial Hypertension. Rev Bras Hipertens. 2001; 8(3):328-38.

8. Badyal DK, Lata H, Dadhich AP. Animal Models of Hypertension and Effects of Drugs. Indian J Pharmacol. 2003; 35:349-62.

9. Guan S, Fox J, Mitchell KD, Navar LG. Angiotensin and angiotensin converting enzyme tissue levels in twokidney, one-clip hypertensive rats. Hypertension. 1992; $20(6): 763-7$.

10. Oparil S. The sympathetic nervous system in clinical and experimental hypertension. Kidney Int. 1986; 30(3):437-52.
11. Ogawa Y, Itoh H, Nakao K. Molecular biology and biochemistry of natriuretic peptide family. Clin Exp Pharmacol Physiol. 1995; 22(1):49-53.

12. Johns C, Gavras I, Handy DE, Salomao A, Gavras H. Models of experimental hypertension in mice. Hypertension. 1996; 28(6):1064-9.

13. Iyer SN, Yamada K, Diz DI, Ferrario CM, Chappell MC. Evidence that prostaglandins mediate the antihypertensive actions of angiotensin (1-7) during chronic blockade of the renin-angiotensin system. J Cardiovasc Pharmacol. 2000; 36(1):109-17.

14. Mensah GA, Croft JB, Giles WH. The heart, kidney, and brain as target organs in hypertension. Cardiol Clin. 2002; 20(2):225-47.

15. Herkner H, Laggner AN, Mullner M, Formanek M, Bur A, Gamper G, Woisetschlager C, Hirschl MM. Hypertension in patients presenting with epistaxis. Ann Emerg Med. 2000; 35(2):126-30.

16. Chobanian AV, Bakris GL, Black HR, Cushman WC, Green LA, Izzo JL Jr, et al.. Seventh Report of Joint National Commiteeon the Prevention, Detection, Evaluation, and Treatment of high Blood Pressure. Hypertension. 2003; 42(6):1206-52.

\section{Correspondence:}

Maria de Lourdes Pessole Biondo-Simões

Rua Ari José Valle, 1987

82030-000 Curitiba-PR Brazil

Phone: (55 41)3297-4359

biondo@avalon.sul.com.br
Conflict of interest: none Financial source: Scientific Initiations Scholarship granted by PUCPR

Received: December 19, 2005

Review: January 23, 2006

Accepted: February 14, 2006

\section{How to cite this article:}

Biondo-Simões MLP, Zazula AD, Gomes AB, Poncio C, Bleggi-Torres LF, Borsato KS. Influence of arterial hypertension treated with Losartan on skin healing in rats. Acta Cir Bras. [serial on the Internet] 2006 May-June 21(3). Available from URL: http://www.scielo.br/acb. 